\title{
O Natal, a alquimia, o tempo, e o espírito: Ou um (neo)fantástico conto de Jorge de Sena
}

Christmas, alchemy, time, and the spirit:

Or a (neo)fantastic tale by Jorge de Sena

Marcelo Pacheco Soares ${ }^{1}$

Resumo: Este artigo investiga «O urso, a pantufa, o quadro, e o coronel», conto de Jorge de Sena, de 1961. Diante de uma narrativa paradoxal que nunca permite concluir sobre o que é sonho ou vigília na noite descrita do personagem, nossa crítica vê-se obrigada a adotar uma metodologia fragmentária do pensamento para levantar hipóteses de leitura para o texto. Chegamos assim, em espelhamento ao título do conto seniano que coordena quatro elementos em sua composição, a um quarteto temático que permitiria circundá-lo: as produções natalinas de Sena, os estudos psicanalíticos de Jung sobre a alquimia, a ideologia de António Ferro no salazarismo, e uma distensão do tempo na narrativa.

Palavras-Chaves: Fantástico novecentista; psicanálise jungiana; tempo; alquimia.

\begin{abstract}
That article focuses on the narrative «O urso, a pantufa, o quadro, e o coronel», a tale of Jorge de Sena written in 1961. Faced with a paradoxical narrative that never allows us to conclude on what is dream or what is vigil on the night described by the protagonist, our criticism is obliged to adopt a fragmentary methodology of thought to raise hypotheses of reading for the text. In mirroring the title of the Senian tale that coordinates four elements in its composition, we arrive at a thematic quartet that allows us to go through at least its perimeter: his Christmas productions, Jung's psychoanalytic studies on alchemy, the ideology of António Ferro in salazarism, and the distension of time in narrative.
\end{abstract}

Keywords: Fantastic $20^{\text {th }}$ century; Jungian psychoanalysis; time; alchemy.

\footnotetext{
${ }^{1}$ Instituto Federal de Educação, Ciência e Tecnologia do Rio de Janeiro. Professor efetivo do Instituto Federal de Educação, Ciência e Tecnologia do Rio de Janeiro (IFRJ). Doutor e Mestre em Literatura Portuguesa pela UFRJ, com Pós-Doutorado em Estudos Literários pela UFF.
} 
Aqui estamos nós, em plena serra, numa pousada isolada pelo temporal, sentados à lareira. É como se o resto do mundo não existisse. Agora, tudo nos pareceria possível.

(Sena, 1966: 193)

Nas camas da Pousada de São Gonçalo, [...] ninguém há que não durma sono profundo, pacífico e reparador. Sono sem sonhos. Porque o Sonho, ali, sonha-se de olhos abertos, olhando em volta, a realidade da Serra do Marão, na sua majestática grandeza e beleza.

(Pinto, 1944: 66)

1.

«O urso, a pantufa, o quadro, e o coronel», conto de Jorge de Sena publicado em 1966 na coletânea Novas andanças do demónio, após frustrada tentativa de ser, segundo o autor, brinde de Natal encomendado por uma editora em 1961 (rejeição que o levou a escrever outra narrativa em substituição, «A noite que fora de Natal», reeditada nesse mesmo volume), edifica-se sobre uma estrutura binária que contraporia a princípio sonho vs. realidade, mas apenas se possível fosse demarcar com precisão em que exato momento começaria ou terminaria cada um. Um imbricamento, porém, desses dois estados de consciência no texto torna seu enredo de tal maneira intangível que, racionalizar sua legibilidade, optamos aqui pela fragmentação como forma de organizar o nosso pensamento.

\section{2.}

No conto, um sexagenário militar reformado, - Coronel Chagas, e seu amigo um pouco mais novo, Doutor Figueiredo, numa tempes- tuosa noite de Natal, chegam a uma isolada pensão serrana, já conhecida pelo segundo. Enquanto fumam à noite no grande salão do hotel, o Doutor apresenta a Chagas a gerente local, Dona Sofia, ainda jovem mulher que enviuvara há dois anos e cuja figura, das unhas bem feitas ao decote ao colo, desperta olhares furtivos do militar. Ela lhes fala sobre a véspera de Natal em que o esposo morrera, lembrando que ele sempre exigia que a pantufa da mulher fosse posta na lareira, e que, naquela ocasião funesta, ainda assim o presente que ele comprara para ela estava pela manhã junto ao calçado, tendo o mesmo acontecido no ano seguinte. Daí que traga consigo no momento uma pantufa vermelha para depositar no mesmo local naquela noite. A história fantasmagórica, que emociona o Coronel, sem que ele nela creia necessariamente, parece causar reação a Figueiredo, porque, lívido, ele se afasta sob o pretexto de tomar ar. Chagas então se aproxima de um quadro que o falecido dono da pousada retocava constantemente, pintura de gênero que parece retratar aquela mesma pousada, ficando sugerido que o próprio velho militar possa ser reconhecido na imagem enquanto chegava à estalagem com o seu amigo. A mulher desaparece repentinamente e o Coronel sobe ao andar dos quartos para procurar Figueiredo, encontrando em seu lugar um homem que traz o estranho recado de que o Doutor resolvera seguir viagem à vila e deixara a pousada com a promessa de retornar na manhã seguinte 
para buscá-lo. Chagas então se recolhe a seu aposento e passa uma fria noite, extremamente mal dormida, em que visões do espaço do quarto, que indicam um semi-sono, se intercalam com seus sonhos ou delírios de passagens diversas da sua vida, inclusive a ocasião da infância em que, na véspera de Natal, sobre a chaminé, teria reconhecido os sapatos de todos os da sua família, dos pais, da avó e dos irmãos, exceto uma pantufa vermelha; naquela mesma manhã natalícia (ou seria outra?), ganhara de presente, segundo as narrativas de suas visões noturnas, um urso de pelo. Após acordar, vai ao salão da pousada e vê o urso junto à pantufa da lareira. Há uma carta para ele, com que, sem ler, o Coronel presenteia o jovem recepcionista da pousada. Encontra o amigo no desjejum, que não sabe dizer a que mulher ele se refere ao perguntar por Sofia. Na partida, no banco de trás do automóvel, ele outra vez vê o urso.

\section{3.}

Reconheceu, certa vez, Mário Sacramento, em recensão ao segundo volume de Andanças (em que, a propósito, elege o conto em análise como o seu preferido): "Se a ficção de Jorge de Sena se realiza incontestavelmente como tal, ela nasce no consórcio do ensaísta com o poeta» (1984: 374).

De fato, intelectual das letras cujo exercício desenvolvia com habilidade, não apenas no terreno da ficção e da poesia, mas também no da crítica, da teoria literária e de outras áreas mais ou menos correlatas, Sena não elaborava sua arte a partir de um mero instinto estético, mas antes consciente, em termos teóricos, do que produzia - traço já consagrado pelos estudos de sua obra. Daí que sua relação com uma literatura tradicional, algo constante em sua produção, não fosse jamais mera emulação de poéticas remotas. Nenhuma ocasião em que o autor aposta em estruturas literárias clássicas representa um renascimento dessas formas, retorno livre de consequências da cultura contemporânea sua. Em artigo recente, por exemplo, sobre a influência anglo-saxônica na obra seniana, Mário Avelar (2019) afirma que «Jorge de Sena evidencia uma capacidade de incorporar contributos no seu próprio exercício criativo, sem jamais cair no epigonismo» (p. 63). Tais linhas de sua poética, o próprio Sena, bem enfaticamente, discutira-as no «Post-fácio» de 1963 à coletânea poética Metamorfoses, advogando que

[...] em nenhum dos meus escritos, jamais defendi um retorno ao «classicismo» ou ao «romantismo», que de ambas as viagens retrospectivas já fui indiciado. «Clássico» e «roo mântico» são termos que só têm duas possis bilidades de sentido, fora das confusões mentais de quem os empregue a despropósito: o sentido periodológico, estritamente estético-histórico (e é absurdo supor-se que alguém, a menos que imbecil - categoria que os meus inimigos me fazem a justiça de não acharem ser a minha -, preconiza o regresso a épocas revolutas e conclusas, que não são socialmente a nossa), e o sentido estético-tipoló- 
gico que fixei num ensaio que goza de algum prestígio internacional (e é absurdo falar-se de regressões escolásticas, onde apenas pode haver análogas atitudes estéticas, verificáveis, através dos tempos, segundo bem definidos planos de análise). (1988: 160)

Pois o mesmo se averigua nas peregrinações senianas pelas searas do fantástico.

\section{4.}

Apesar disso, não são raras as vezes em que alguns desses fantásticos contos das suas $\mathrm{An-}$ danças (não apenas as novas mas também as então chamadas antigas, isto é, as do primeiro volume publicado em 1960) são aproximados da tradição da literatura oitocentista ou mesmo anterior, como «A campanha da Rússia» e seus fantasmas, «O grande segredo» e a possessão diabólica da freira ou o ambiente mágico-fabulista de «História do peixe-pato» ou de «Kama e o génio», o que se dá erroneamente se não se leva em consideração as particularidades que transformam tais produções em textos prioritariamente novecentistas.

«O urso, a pantufa, o quadro, e o coronel» parece ser lido, nas poucas vezes em que a crítica lhe confere atenção, como exemplo das obras do século XIX que Tzvetan Todorov identificou como genuinamente fantásticas. Óscar Lopes, para ficar em exemplo mais notório, afirma que o conto

[...] pertence àquele tipo de narrativa que Todorov classifica de «fantástica», em opo- sição a «maravilhosa», porque permite várias chaves de interpretação dentro do verossímel corrente, deixando no entanto a sugestão de uma outra verossimilhança transcendente a esse real quotidiano. (1984: 328-329)

Nota Primeira: Todorov, em sua afamada pesquisa de 1968, Introdução à literatura fantástica, defende que o fantástico «teve uma vida relativamente breve [...], os contos de Maupassant representam os últimos exemplos esteticamente satisfatórios do gênero» (2004: 174-175), limitando fortemente aos 1800 as suas efetivas aparições. Para o ensaísta, a verificação na narração de uma hesitação entre uma leitura realista e outra mágica, autoexcludentes, seria, dentre outros predicados que elenca, artifício fundamental à sua construção: «O fantástico é a hesitação experimentada por um ser que só conhece as leis naturais, face a um acontecimento aparentemente sobrenatural» (p. 31).

No fantástico do século XX, porém, pós-Kafka, não observamos, como antes, uma simples ruptura, mas uma contaminação do real pelo irreal, uma amálgama entre esses mundos, como, ademais, reconhecera o próprio Todorov ao apresentar «a diferença entre o conto fant tástico clássico e as narrativas de Kafka: o que era uma exceção no primeiro mundo torna-se aqui uma regra» (p. 182) - daí que seus personagens não hesitem, porque se tornam eles mesmos fantásticos. Nesse aspecto, aliás, o argentino Jaime Alazraki, que em suas pes- 
quisas sobre a manifestação hodierna do gênero criou, a partir do último quarto de século, a difundida nomenclarura neofantástico, aponta-nos que

\footnotetext{
[...] si lo fantástico asume la solidez del mundo real - aunque para «poder mejor devastarlo», como decía Callois -, lo neofantástico asume el mundo real como una máscara, como un tapujo que oculta una segunda realidad que es el verdadero destinatario de la narración fantástica. (2000: 276)
}

Tais conceitos aproximam sobremaneira o fantástico do século XX de um inegável realismo, na medida em que aposta numa poética que não se divorcia da realidade promovendo uma literatura escapista, mas antes faz de si um meio, muitas vezes mais eficiente do que a técnica realista, para discutir o mundo real. ${ }^{2}$

\section{5.}

Seguindo tal ótica, Maria de Fátima Marinho afirma que, em «O urso, a pantufa, o quadro, e o coronel», «a fronteira entre o real e o imaginário é muito ténue, não se conseguindo estabelecer definitivamente de que lado se situa a diegese. Esta hesitação convém perfeitamente à mentalidade surrealista, evoluindo a oposição sonho/realidade para uma síntese ideal»

\footnotetext{
2 Sobre o fantástico pós-Kafka, compilamos e discutimos análises teórico-críticas suas em nosso trabalho «A literatura fantástica do século XX e a representação do real» (2015).
}

(1987: 183). Não será esse conto, é claro, um texto surrealista (nem mesmo é isso, esclareçamos, que Marinho defende). Mas a ideia da ensaísta de uma oposição (e aproximamo-la aqui da ambiguidade todoroviana) que evolui para uma síntese (contaminação do real pelo irreal, como dissemos) dá conta, justamente, do quanto essa narrativa de Sena está mais vinculada, como não poderia deixar de ser, a um fantástico novecentista do que ao produzido no século anterior. Destaque-se que seu protagonista jamais demonstra um sentimento de espanto em relação aos episódios que testemunha, agindo com naturalidade e sem as hesitações todorovianas diante da sucessão de quebras de causalidade que experiencia - haverá, provavelmente, um desconforto racional do leitor, que não conta, porém, com a cumplicidade de um, nesses casos, impassível Coronel; tal traço comportamental aproxima-o antes dos que circulam pelas obras do realismo mágico latino-americano, de que o conto é contemporâneo, ou dos heróis kafkianos. Quanto a isso, Margarida Braga Neves, com muita justeza, ressaltará sobre as $A n$ danças senianas que

[...] na verdade em Sena o fantástico não só não se opõe à realidade, como, pelo contrário, lhe apõe uma lente através da qual a observa, ampliando-a nos seus mais ínfimos pormenores. E por isso a imagem que o texto devolve, nítida nos seus contornos e iluminada nos seus recantos mais recônditos e secretos, não serve para a (dis)simular mas antes para 
alargar, revelando a sua textura rugosa, a aspereza das suas alinhas, a contorção das formas e a distorção dos volumes, numa afirmação do carácter tantas vezes grotesco da realidade. (2008: 20-21)

A observação de Braga Neves localiza com precisão o ponto em que a poética seniana pousa na linha temporal da literatura fantástica, indicando sua produção como genuína manifestação novecentista do gênero. Dessa maneira, Sena (também) aposta no fantástico como instrumento de clarividência que combate uma alienação da realidade.

\section{6.}

O autor mesmo não se furta a discutir suas narrativas do gênero. No prefácio às Novas andanças do demónio, acolhe a ideia de que seu fantástico é uma forma eficiente de representar a realidade, com maior potencial para descrever o real do que o próprio realismo ortodoxo - essas grandes máquinas realísticas que considera então impossíveis e falsas:

Mesmo uma total fantasia, ou o aproveitamento de elementos dela, pode permitir uma intensidade realística que seria, em «atualidade», muito mais chocante para os delicados e virtuosos que, neste mundo, comandam os nossos destinos, ou preparam, solícitos, a nossa inescapável salvação. É certo que, no plano da aparente fantasia, a intensidade realística, se, por um lado, é como uma pílula dourada (que podemos usar nos tratamentos que não são de choque), pode, por outro lado, ser muito mais irritante, porque, não tendo o escape da representação convencionalmente atual, atinge e fere lá onde se escondem, fern ventes e tórpidos, os recalques e complexos mais profundos. (1989: 221)

Reflete assim que esse discurso poético expõe o que o senso comum não percebe da realidade (e, desse modo, Sena assume o mundo real como uma máscara que oculta uma segunda realidade), tornando-o um modo de revelação:

Com que autoridade imaginamos personagens que passam de capítulo a capítulo, quando a suspensão do mundo não consente nem justifica a unidade interior de ninguém? Com que direito supomos uma sequência lógica dos acontecimentos, quando a lógica da causalidade se perde em nexos que sabemos mais vastos? Com que autencidade nos damos a descrever uma realidade, fingindo-a real, se a realidade é, em si mesma, outra? Por isso, sejamos objetivos com a fantasia, e subjetivos com a realidade. (p. 222)

Trata-se, ainda em suas palavras, de pôr em xeque a concepção de realidade que fora falseada por outros para que nos conformemos com ela, o que implica um discurso político-revolucionário que, como se verá, nunca se subestima em Sena.

\section{7.}

Então, o fantástico de «O urso, a pantufa, o quadro, e o coronel» residirá na fundição de uma pretensa ambiguidade, não se tratando mais do «isto ou aquilo» da teoria de 
Todorov, mas de um «isto $e$ aquilo», porque, enfatizemos, em momento algum é possível precisar qual parte da narrativa é realidade e qual fragmento seu se encontra na esfera do sonho ou do delírio, se houver um ou outro, o que entrelaça de modo irrevogável os dois mundos possíveis, criando talvez uma terceira nova realidade em que essas fronteiras deixaram de existir. Provavelmente por isso, em nota explicativa sobre o conto, Jorge de Sena revele: "Quanto ao conto da pantufa, [...] eu mesmo não saberia dar a chave do mistério, se o é» (p. 226) - proposição que nos chama a atenção inclusive pela possibilidade levantada de não haver aqui o que se investigue na camada mais superficial do enredo da narrativa, o que está reforçado pela sua veemente condenação, no citado «Prefácio» de 1966 às Novas andanças do demónio, de que «contos de fantástico realismo devam ser entendidos como parábolas simbólicas» (p. 222). Somos, entretanto, leitores subversivos e, preferindo entender essas espécies de conselho como retórica desafiadora, apostamos na existência dessas chaves.

8.

É preciso atentar para a temática natalina do conto, a incluir em uma potencial coletânea da obra do autor, cujo volume final teria tido sem dúvida algum peso. O Natal é uma ocasião muito propícia à poética seniana, que produz sobre a data não apenas contos («Razão de o Pai Natal ter barbas brancas» é mais um das
Andanças do demónio - o primeiro volume que poderíamos citar, unindo-o aos dois já mencionados), mas especialmente poemas. Ao aproveitar a data festiva para desvelar os desvalidos (os famintos, os abandonados por Deus, os que sofrem e morrem na Segunda Guerra Mundial ou nas Guerras Coloniais ou são calados pelo Estado Novo português contextos da maioria dessas composições), o poeta encara com desesperança e melancolia a data que a sociedade, amiúde menos sincera do que hipocritamente, usa para enaltecer valores ditos positivos, os quais, porém, the parecem servir apenas como anestésico que a impede de encarar os males do mundo. Daí que, em um dos seus trabalhos mais pungentes, «Natal», de 1943, o poeta descreva os horrores da Guerra e, contrapondo os festejos pelo nascimento de dois mil anos antes, traz em seu dístico final o infanticídio em massa causado pelos conflitos bélicos: «Crianças se sumiram no incêndio... / Que rósea aurora as ressuscitará?» (1988: 140) - pergunta provocadora que ele retomará no fim do poema «Sobre uma antologia lírica do Natal - 1969», a que se seguirá a constatação: «(há já vinte anos perguntei - não digam)» (1978: 111). Esses «antinatais» senianos - assim os batizou Eugénio Lisboa - são, pois, igualmente, peças de clarividência a combater uma alienação da realidade. 


\section{9.}

Nesse conto, porém, ao contrário dos poemas, que se identificam sempre sob ano claramente referenciado, parece-nos que estamos diante de uma sobreposição de Natais. Tal efeito alcança-se em razão de uma imprecisão temporal constante na narrativa. No início, enquanto aguarda a meia-noite que anuncia o 25 de dezembro, o Coronel verifica que seu relógio está três minutos atrasado em relação ao do salão da pousada: «o meu relógio atrasa-se assim estes minutos, e aqueles relógios funcionam muito bem, quando estão regulados» (SENA, 1989: 186), explica Chagas, ao que Figueiredo levanta a hipótese de que o aparelho local não estivesse calibrado, mantendo a indefinição e sugerindo uma distensão temporal (quebra da linearidade temporal da narrativa) que se testemunhará.

Também a pantufa vermelha que aparece nos sonhos do Coronel e que ele não reconhece quando criança - e esta é a história que tenta contar ao Doutor desde a noite, fazendo-o somente no desjejum do dia seguinte, sem aliás precisar nunca se é um episódio dos seus 8 ou 12 anos - é a mesma peça que ele só poderia ter visto no encontro com Dona Sofia, já idoso. Assim é que, sob um fluxo de consciência, os Natais surgem embaralhados ou em paralelo, em espaços-tempos distintos mas chocando-se entre si - e não apenas no auge das visões noturnas, quando o fenômeno se intensifica nitidamente, mas também pela manhã (lembremos a presença do urso de pelo na lareira e no banco traseiro do automóvel).

Semelhante confusão temporal ocorre ainda com o quadro do salão, já que o Coronel titubeia em lhe precisar a época: «E estão todos vestidos... não sei a que moda. 0 estalajadeiro, é difícil saber-se. Os dois sujeitos... bem, pode ser tanta coisa... Século Dezoito, até século passado também, com aquelas casacas e aqueles calções... Ah, mas são calças, é mais recente [...]» (p. 189). Desse modo, o quadro igualmente traz uma sobreposição de tempos, não apenas resultante dos retoques do falecido gerente, mas ainda porque, como dissera o Coronel ao amigo, se tratava de «uma imitação servil e desajeitada de uma cópia qualquer que já não era boa» (p. 185).

O quadro, portanto, torna-se uma metalinguística metáfora autoirônica desse conto, que apenas parece emular uma narrativa fantástica tradicional, poética em palimpsesto, que permite a Sena também retocar o gênero acrescendo-lhe traços de estilo eminentemente novecentistas e «os retoques pareciam despegar-se nitidamente de uma camada mais antiga» (p. 190). Mas será o mesmo quadro ainda signo desse fenômeno de uma simultaneidade temporal que se espalha pela narrativa, fazendo-nos crer que, no espaço fantástico da pousada, vários Natais se sincronizam, permitindo assim que Dona Sofia continue recebendo os presentes do marido falecido em sua pantufa vermelha, a qual aparece ao 
mesmo tempo nas lembranças longínquas de um Natal da infância do Coronel, em que ele ganhou o urso de pelo, que reaparece agora nesse Natal de sua velhice.

\section{0.}

Outra possibilidade de leitura estaria ligada à origem do cenário do conto, já que, como o próprio Sena atesta em sua nota sobre a narrativa, a estalagem em que os dois amigos se abrigam da tempestade era «uma pousada montanhesa e de luxo, que se estava mesmo a ver que podia ter sido a do Marão» (p. 225). A Pousada Regional de São Gonçalo, localizada na serra do Marão (nas fronteiras entre o Minho, o Douro e Trás-dos-Montes), foi edificada em 1942 (com atraso, porque deveria ter ficado pronta por ocasião das festividades do Duplo Centenário da Fundação e Restauração de Portugal, em 1939) - e enfatizemos a pequeníssima diferença de datas (tão pequena que escancara mais uma manifestação de uma disrupção temporal) entre a que Sena usa para datar o conto (30 de agosto de 1961, algo estranha para uma narrativa destinada a ser brinde de Natal daquele ano, embora não saibamos a antecedência da solicitação da editora) e a da real inauguração da Pousada do Marão (29 de agosto de 1942, tendo aniversariado na véspera daquela data e estando a passar por reformas de ampliação nesse mesmo ano de 1961). O hotel surgira na esteira do projeto chefiado por António Ferro, ideólogo do Estado Novo, de criar uma rede de pousadas regionais que atraíssem os turistas para um ambiente bem reservado, que servisse de propaganda de um país bucólico e familiar. Segundo o cientista político Orlando Raimundo:

\begin{abstract}
Os preços são relativamente baratos, para o poder de compra da generalidade dos estrangeiros que não podem pernoitar mais de três noites seguidas em cada uma delas, numa estratégia destinada a evitar que possam vir a aborrecer-se e que resulta em pleno. $\mathrm{O}$ aviso de António Ferro aos gestores dos espaços não podia ser mais explícito: «Quando um hóspede deixar de ser tratado pelo nome, para ser conhecido pelo número de quarto que ocupa, estaremos completamente desviados do espírito das Pousadas».

O turismo é para ele não só um «fator de riqueza e civilização», mas sobretudo um «meio seguríssimo de alta propaganda nacional», para inglês ver, e de «simples propaganda política» de consumo interno. (2015: 222)
\end{abstract}

A arquiteta Susana Lobo fizera semelhante leitura ao descrever, nas pousadas, os

$$
\begin{aligned}
& \text { [...] subtis enquadramentos de sabor rústico, } \\
& \text { agenciados pelos artistas do SPN [o Secreta- } \\
& \text { riado de Propaganda Nacional, chefiado por } \\
& \text { Ferro de } 1932 \text { a 1950] sobre idílicas interpre- } \\
& \text { tações de uma vivência rural que se prestava } \\
& \text { ao imaginário nacionalista e conservador do } \\
& \text { Regime. (2016: 45) }
\end{aligned}
$$

A carga ideológica que o espaço emana, portanto, legaria ao conto uma leitura que 
levaria mesmo a desconfiar sobre o que fariam ali, em plena noite de Natal, o Coronel e o Doutor (a alcunha deste referindo-se a atividades advocatícias, dada a menção à procuração que ele solicita para vender a quinta de Chagas) e quais seriam seus destinos entre Porto e Lisboa, não revelados.

Dentre os fragmentos das visões de Chagas, aliás, sugere-se sua atividade no Golpe de 1926, na lembrança de que «o general tinha telefonado, a revolução era um facto consumado sem tiros» (1989: 193). Desse modo, se no primeiro poema de Arte de música, «"La cathédrale engloutie", de Debussy», Sena, em menção à sua infância, fala de «almas penadas como as do Marão e que eu temia / em todos os estalidos e cantos escuros da casa» (1968: 10), diríamos que, dada a época da escrita do conto, agora, na maturidade de Sena, a provocarem bem mais do que estalidos nos cantos escuros da casa - a «casa portuguesa, com certeza» em que o salazarismo transformara o país -, as figuras fantasmáticas refeririam alegoricamente outras tão ou mais temíveis do que os espíritos típicos da literatura oitocentista, aqui no campo político e social: e lembremos que a missão que Salazar confia a António Ferro é precisamente a de implantar a estetizante «Política do Espírito».

Nota Segunda: Um ano antes de assumir o SPN, António Ferro escrevera uma série de artigos no Diário de Notícias, quando cunhara a «Política do Espírito» em texto de 21 de no- vembro. Ele assim explica o sintagma, já em um discurso de 1934:

\begin{abstract}
Política do Espírito é aquela que se opõe, fundamental e estruturalmente, à política da matéria [...], é estabelecer e organizar o combate contra tudo o que suja o espírito, fazendo o possível para evitar certas pinturas viciosas do vício que prejudicam a beleza, como certos crimes e taras ofendem a humanidade, a felicidade do homem. Defender a Política do Espírito é combater sistematicamente [...] tudo o que é maléfico, doentio, por simples volúpia ou satanismo! (apud Torgal, 2009: 124)
\end{abstract}

Ora, é por fazer de sua literatura resistência a tais disposições moralistas, conservadoras e censoras do salazarismo (ou de qualquer outra ditadura) que Sena marca sua obra precisamente pelo signo do diabo (como é desnecessário uma vez mais explanar), do satânico que arrepia Ferro, sendo por isso inconcebível pensar, a partir de tal contexto, que, no conto em análise, a transformação do corpo em espírito, prescrita desde a epígrafe, possa vir a ser algo alvissareiro.

\section{1.}

A propósito, quanto a essa epígrafe, ei-la:

E ouvi uma voz do Alto que me dizia: - Cumpri a ação de descer os quinze degraus para as trevas, e a ação de ascender os degraus para a luz. O sacrifício renova-me, rejeitando a densa natureza do corpo. Assim consagrado pela necessidade, tornei-me espírito. Zósimos de Panápolis. (Sena, 1989: 183) 
Místico gnóstico egípcio (ou talvez grego) da virada do século III para o IV, Zósimos consta como autor dos mais antigos livros da alquimia. Em um dos seus textos mais difundidos, descreve uma série de noturnas visões fantásticas interrompidas por breves momentos de vigília, nos quais acerca delas reflete. Os sonhos limitam-se a variantes de uma mesma cena: um amplo altar em forma de taça rasa, com 15 degraus, que é palco desde discursos de um sacerdote (a «voz do Alto» da epígrafe), que se autossacrifica nas águas, até a imagem de várias pessoas sucumbindo nessas mesmas águas então ferventes a separarem seus corpos e almas, passando por torturas que envolvem desmembramentos e escalpelamentos, tudo a representar os processos alquímicos da composição das águas, os quais Zósimos sói decifrar para transformar o cobre em prata e ouro. Repare-se que a vasta referência aquática também envolve os acontecimentos do conto de Sena, através da forte tempestade, assídua a toda a narrativa. Ora, em artigo de 1954, intitulado «As visões de Zósimo», o psiquiatra suíço Carl Jung, em cujo livro de 1944, Psicologia e alquimia, já analisara psicanaliticamente os sonhos do egípcio, acrescenta que «a alquimia [...] trata da água milagrosa, da aqua divina ou permanens, que é extraída da lapis, isto é, da prima materia mediante a tortura do fogo. [...] A água divina possui uma capacidade de transmutação em geral» (1986: 89) - como, a propósito, também o faria o gênero fantástico.
Nota Terceira: É mesmo possível que a obra do psicanalista estivesse em evidência em 1961, ano de produção do conto - reiteremos, concluído em agosto, segundo Sena -, pois fora também o ano do falecimento do médico, pouco antes, em junho. Sena poderia já ter alcançado a obra do gnóstico grego em razão de seu interesse pela alquimia (estamos a falar de um autor que tem Pedra filosofal como título de um de seus livros poéticos e cujo personagem talvez mais importante, seu físico prodigioso, é também um alquimista), mas seria igualmente factível que o tivesse alcançado em suas leituras de estudos psicanalíticos. É interessante notar ainda que as posturas éticas de Jung e Sena sobre sentimentos religiosos e suas contestações ao mito do Deus da cristandade dialogam de modo largo (assunto, contudo, que não cabe agora aprofundar).

\section{2.}

As interposições entre momentos de sono e de espertina no texto de Zósimos assemelham-se à noite mal dormida do General Chagas, de que trazemos trechos que demonstram análogas intercalações entre os sonhos e presumíveis vigílias:

Estendeu a mão para o relógio, eram duas e dez. Levantou-se, foi à casa de banho, seguido pela Maria que fora enterrada com aquele vestido preto, e bebeu um copo de água. Veio sentar-se na borda da cama. Pegou no sapato. Esquecera-se de o pôr na chaminé. Desceu a escada que era um corredor comprido, onde ele fingia que a passadeira eram os carris de 
uma via férrea, e o comboio vinha, do lado da sala, apitando e fumegando, a uma velocidade incrível. [...] A chuva recomeçara, mas não caía violentamente. $\mathrm{E}$ a porta do guarda-fato abria-se devagar, o Figueiredo, curvado, com o cabelo a brilhar de penteado, desceu dele e fechou a porta. E aproximou-se, em pijama azul, da maleta. O coronel sentou-se na cama, e disse: - Figueiredo, por onde andou você? - O Figueiredo olhou para ele, com a maleta na mão, e fez-lhe sinal que se calasse, sorrindo afetuosamente; e entrou na casa de banho. O coronel sentiu, repentinamente, que não tinha ninguém, e entrou na loja de antiguidades, atrás do Figueiredo. (Sena, 1988: 193-195)

Aqui, porém, o espaço do quarto apenas sugere instantâneos de lucidez despertada («estendeu a mão para o relógio, eram duas e dez; levantou-se, foi à casa de banho; bebeu um copo d’água; a chuva recomeçara; o coronel sentou-se na cama») ou aqueles momentos em que se sonha que acordou. Dissolvem-se as fronteiras entre as imagens do aposento e episódios claramente oníricos, amalgamando os dois estados de consciência. Potencializa o fenômeno o fato de as lembranças que Figueiredo terá pela manhã acerca da noite anterior não serem, mesmo com elementos que as evidenciem, aquelas a que o leitor assistiu. E toda a realidade da narrativa é tomada pela atmosfera de sonho ou, por extensão, a nossa realidade física (ou a sua ilusão) estraçalha-se mimetizada a partir do substrato onírico que lhe seria inerente.

\section{3.}

O trecho de Zósimos eleito por Sena para sua epígrafe é precisamente fragmento do texto estudado por Jung. Sobre as escadas de 15 degraus descritas pelo alquimista, analisa o médico suíço: «o tema dos degraus e das escadas indica o processo de transformação anímica e suas peripécias. Zósimo dá-nos um exemplo clássico disso, com sua ascensão e descida pelos quinze degraus de luz e escuridão» (Jung, 1991: 72). Ora, por todo o conto, o Coronel sobe e desce escadas - as da pousada, que se transfiguram nas de sua casa na infância. E se testemunhamos, no decorrer do processo que é, afinal (como veremos), justamente de transformação anímica, um circuito de imagens confusas, é porque, para Jung, «o caminho para a meta a princípio é caótico e imprevisível» (p. 39). Por isso, também, ao partir da pousada, o automóvel dos dois homens desce por uma «estrada perigosa, húmida, cheia de curvas» (Sena, 1989: 199) - aliás, a Curva da Morte em frente à qual foi de fato construída a Pousada do Marão -, que ora revela, ora esconde a imagem da estalagem (e a estrada é a nova forma dos degraus de Zósimos que o Coronel subira para a luz e pelos quais agora descia para as trevas, desfecho, afinal, positivo, se encararmos o binômio luz vs. trevas sob uma lógica ética e irrevogavelmente inversa à dos discursos de António Ferro). A pousada seria então uma autorrepresentação do Coronel, arquétipo jungiano. 
Nota Quarta: Em sua autobiografia Recuerdos, sueños, pensamientos, de 1957, Jung interpreta em seus sonhos o arquétipo da casa como representação da sua personalidade: «siempre se repetía el mismo motivo: junto a mi casa había otra, es decir, un ala, o un anejo, que me era desconocido» (p. 240), ao que conclui: «El ala del edificio para mí desconocida constituía uma parte de mi personalidad, un aspecto de mí mismo; representaba algo que me pertenecía, pero que todavía no me era consciente» (p. 241). Teve ele outro sonho com uma casa cujas análises de Freud desagradaram Jung, precipitando seu rompimento metodológico com o então mestre, porque lhe era «evidente que la casa representaba un tipo de psiquis, es decir, mi estado de conciencia de entonces com sus complementos hasta entonces ignorados» (p. 193).

\section{4.}

Ainda na investigação de Jung, o simbolismo dos números três e quatro na alquimia surge-nos como elemento importante à leitura do conto. Segundo o psiquiatra:

O número três não é uma expressão natural da totalidade, ao passo que o número quatro representa o mínimo dos determinantes de um juízo de totalidade. E preciso ressaltar no entanto que ao lado da nítida tendência para a quaternidade da alquimia (como também do inconsciente), sempre há uma incerteza marcante entre o três e o quatro. [...] O quatro significa o feminino, o materno, o físico; o três, o masculino, o paterno, o espiritual. A incerteza entre o quatro e o três significa portanto o mesmo que a hesitação entre o espiritual e o físico: um exemplo marcante de que toda verdade humana é apenas uma penúltima verdade. (1991: 37)

Retomamos através de Jung a oposição espiritual vs. material que encontramos na epígrafe de Zósimos e na ideologia de Ferro. Ademais, observemos que o título do conto em análise é justamente quaternário, mas fora ternário, segundo confessa Sena: «escrevi O Urso, a Pantufa, o Quadro, e o Coronel, que remeti (sem “quadro" no título)» (1989: 225). Sua opção, portanto, da ampliação posterior - e, mais, esse fortuito esclarecimento que não queremos crer inocente - promove com mais clareza a alternância do protagonista entre suas existências física e espiritual (por expansão, entre os pares paternidade e maternidade e masculino e feminino, que igualmente transpassam a narrativa).

Se o conto representaria uma autorreflexão psicanalítica do Coronel, justifica-se a regressão que se constrói sobre sua vida, fragmentada na madrugada, a incluir rotinas de quartel e um soldado alemão morto (provavelmente, em campanha nas fronteiras das colônias africanas na Primeira Guerra Mundial), presenças da avó e da mãe entre afetos e flagras sexuais (a instigar seu Complexo de Édipo), relacionamentos amorosos, casamento, morte do filho e da esposa e de quase todos os familiares, proximidade com sobrinhos, além de algumas passagens com o Doutor Figueiredo desde a 
infância (o que parece menos factual do que nova de sobreposição temporal). Cabe pensar, aliás, se o personagem do amigo não seria uma espécie de consciência auxiliar sua, superego, que simbolicamente o guia pela pousada e dirige o carro em que transitam, mas que ambiguamente, por sua função psíquica censora e repressora, o aproximaria (numa associação mais livre de ideias) de uma representação da ditadura: e sublinhemos que é na sua ausência que Chagas está liberto para vivenciar o processo da madrugada, após o qual consegue afinal verbalizar a história que não the era possível concretizar em fala na noite anterior, indicativo de alguma mudança em si.

Destacam-se também dentre as visões as referências à filha, Lúcia - do latim lux, um dos sentidos, portanto, da epígrafe que prevê um caminho para a luz -, nome também de uma antiga namorada sua, coincidência que sugere um Complexo de Electra na contramão, reforçado pela aparição de uma Dona Sofía à janela da pousada, «cujos seios pousavam nus no peitoril, muito redondos, com os mamilos róseo-escuros» (p. 193), a qual, mais à frente, o abraçará exatamente dizendo: «Meu pai, meu pai» (p. 195). Após envolvimento com um empregado da quinta, que Chagas então castiga fisicamente (reação que reforça a evidência do complexo), Lúcia saíra de casa, mais tarde escrevendo-lhe em carta: «Meu pai, sabe bem que não poderia voltar» (p. 192).
As visões de Chagas seriam um embate, no seu inconsciente, do personagem consigo mesmo: daí que, se, no início da noite, resiste em encarar-se - «lavou as mãos cuidadosamente, sem olhar para o vulto que se projetava no espelho» (p. 191) -, pela manhã já o faça, ainda que em superfície que não o delineia por inteiro - «No espelho, embaciado pelo vapor do banho, que enevoava o quarto, viu se estava perfeitamente em ordem» (p. 196). E isso não ocorre apenas porque «toda verdade humana é apenas uma penúltima verdade», como diz Jung (1991: 37). Há uma aparente resistência de Chagas em espiritualizar-se e «ascender os degraus para a luz» (Sena, 1989: 183) - que, afinal, é sua filha -, ratificada na carta que encontra pela manhã e não lê: e que duplica a carta de Lúcia (a filha? a amante? quem mais?). Caso Sena soubesse «dar a chave do mistério», (p. 226) talvez tivéssemos (personagem e leitores) acesso ao seu conteúdo. Chagas entrega a carta ao rapazote da recepção, que nos sonhos da madrugada é identificado com o empregado chicoteado (superação do Complexo de Electra?), mas poderia ser ainda um duplo do próprio Coronel (distensão temporal novamente) ao tornar-se alguém que ganha do velho o ensejo de refazer caminhos que ele mesmo não mais pode corrigir.

Nota Final: Fosse essa a «chave do mistério» e, quem diria?, esse conto fantástico de Jorge de Sena terminaria com um milagre de Natal. 


\section{Bibliografia}

Alazraki, J. (2000). ¿Qué es lo neofantástico? Em: D. Roas. Teorías de lo fantástico. Arco/Libros. Madrid;

Avelar, M. (2019). O anglicista Jorge de Sena. Colóquio/Letras. 200: 54-64;

Jung, C. (1986). As visões de Zósimo. Em: Estudos alquímicos. (Trad. de M.L. Appy et al.). Vozes. Petrópolis;

Jung, C. (1991). Psicologia e alquimia. (Trad. de M.L. Appy et al.). Vozes. Petrópolis;

Jung, C. (2002). Recuerdos, sueños, pensamientos. (Trad. de M.R. Borras). Editorial Seix Barral. Barcelona;

Lisboa, E. (1987). Os antinatais de Jorge de Sena. Em: As vinte e cinco notas do texto. Imprensa Nacional-Casa da Moeda. Lisboa;

Lobo, S. (2006). Pousadas de Portugal: Reflexos da arquitectura portuguesa do século Xx. Imprensa da Universidade de Coimbra. Coimbra;

Lopes, O. (1984). Os contos de Jorge de Sena (problemas de um assumido realismo). Em: E. Lisboa (comp., org., introd.). Estudos sobre Jorge de Sena. Imprensa Nacional-Casa da Moeda. Lisboa;

Marinho, M. de F. (1987). O surrealismo em Portugal. Imprensa Nacional-Casa da Moeda. Lisboa;

Neves, M.B. (2008). Os contos impublicáveis de Jorge de Sena. Metamorfoses. 9: 17-28;
Pinto, A. (1944). Digressão turística à volta da Pousada de São Gonçalo. Panorama - Revista Portuguesa de Arte e Turismo. 19: 63-66;

Raimundo, O. (2015). António Ferro: O inventor do salazarismo - mitos e fasificações do homem da propaganda da ditadura. Dom Quixote. Alfragide;

Sacramento,M.(1984). Recensão crítica de Novas andanças do demónio. Em: E. Lisboa (comp., org., introd.). Estudos sobre Jorge de Sena. Imprensa Nacional-Casa da Moeda. Lisboa;

Sena,J. de. (1966). Novas andanças do Demónio. Portugália. Lisboa;

Sena, J. de. (1968). Arte de música. Moraes Editores. Lisboa;

Sena, J. de. (1978). Quarenta anos de servidão. Moraes Editores. Lisboa;

Sena,J. de. (1988). Poesia II. Edições 70. Lisboa;

Sena, J. de. (1989). Antigas e novas andanças do demónio: Contos. Edições 70. Lisboa;

Soares, M.P. (2015). A literatura fantástica do século XX e a representação do real. Revista de Letras. 55 (2): 117-135;

Todorov, T. (2004). Introdução à literatura fantástica. (Trad. de M.C.C. Castello). Perspectiva. São Paulo;

Torgal, L.R. (2009). Estados novos, Estado Novo: Ensaios de história política e cultural. Imprensa da Universidade de Coimbra. Coimbra. Vol. 2. 